\title{
8 Disaster, Relief and Political Change in Southern Ethiopia: Developments from within Suri Society Jon Abbink
}

\section{INTRODUCTION}

The early 1990s saw substantial changes in the Horn, especially in terms of politics and socio-economic organization. Previous dictatorial structures chaacterized by political stagnation and economic crises were brought down by demands for democratization, economic restructuring, ethnoregional rights and state independence. The process of change in Ethiopia after demise of the Mengistu regime in 1991 resulted in a remarkable turn toward 'ethnicization' of political and public life under a Transitional Government (TGE) led by the former rebel movement Ethiopian Peoples' Revolutionary Democratic Front (EHADIG, in its Amharic and Tigrinya acronym). Explicit recognition of ethnic groups or 'nationalities' as units on which to base political parties and regional administrative structures is being incorporated in the new constitution and being adopted in education and language policies. Whether positive or negative, its future effects on development policy execution, through the Ethiopian government or through foreign NGOs, will be significant.

For some observers, these changes in state structure and national discourse hold an example for other African countries, while for others recalling violent ethnic clashes of the past - they are a recipe for disaster (cf. Walle 1993). Be that as it may, this new discourse on national identity, ethnic group relations and the 'development effort' will shape future social and politico-economic developments, if only by creating new ideological realities.

In the past few years, the new decentralizing approach affected some ethno-regional groups more than others. Larger ethnic groups have (often forcibly) been involved in political and ideological struggles to redefine their 'identities' within a new national political arena, the boundaries of which are still contested. But other groups remain at the margins. Recent 
discourse on change and development has been mainly confined to ideological squibs related to the TGE's ethnic policy-approach and to the criticism of its various rivals such as the OLF (Oromo Liberation Front), the AAPO (All-Amhara Peoples' Organization), the COEDF (Coalition of Ethiopian Democratic Forces), or the SEPDF (Southern Ethiopian Peoples' Democratic Front). Less attention has been paid to local-level perceptions and aspirations of average inhabitants not involved in party or ethnic politics. Here, first hand data - even on large 'nationalities' like Amhara, Oromo, Tigray, Sidama, Wolaita, Afar, etc. - are indeed scarce.

In this chapter, I describe responses to recent socio-ecological crisis and political process among the Suri, an agro-pastoral group in Ethiopia's southwestern Käfa Region. Data come from fieldwork done after the change of regime in 1991. Effects of natural disaster as well as political changes are considered in order to trace the recent history of a group only marginally involved in national politics. Even at this level however, important points about national politics, ethnicization and group relations arise.

The Suri number about $24,000,{ }^{1}$ live in a remote border-area of Ethiopia and Sudan, and are perhaps even less touched by 'outside forces' than the famous Yanomamo, described by Chagnon (1992) as one of the world's last 'true' tribal peoples. News about the Suri is never reported anywhere, not even in the Ethiopian press.

In past decades, the Suri witnessed serious ecological and societal crises. They faced drought, crop shortages, cattle disease, and violent confrontations with neighbouring peoples, leading to severe disruption of traditional modes of subsistence and serious reduction of their population. As they were at Ethiopia's politico-economic margins, they were not provided with substantial external aid from either the government or international aid agencies. Through various strategies like temporary migration, increased hunting and gathering, exploitation of gold resources and investment in, and use of, automatic weapons for attack and defence, a group response to societal survival was formulated. It culminated in full recovery of the economic and socio-cultural fabric of their society, but at the cost of increasing isolation and violent conflict with all their neighbours, including the former Derg administration as well as the new EHADIG authorities.

The Suri, as a relatively homogeneous and solidary population, must be considered as one interacting part in the wider natural and socio-political environment, i.e., not only must determining factors in their eco-niche be taken into account but also those of the regional-political context of the Ethiopian state, of which they and most of their neighbours nominally have been a part since 1898. Both spheres impinge on each other and consideration of developments after 1991 are of interest to evaluate changes in a long-term perspective. Part of the story of their successful 'indigenous' recovery is indeed that of their changing political relations with other ethnic groups and agents in their area.

\section{THE SURI ENVIRONMENT AND SUBSISTENCE SYSTEM}

It is of course impossible to speak of ethnic or tribal groups as if they were 'primitive isolates', but the Suri can be described as a relatively remote and untouched population. Their area is one of the most inaccessible and neglected parts of Ethiopia. It was nominally conquered in 1898, when the army of Ethiopian emperor Menilik II passed southward to the borders of British-held territories (Sudan and Kenya). Even today, after ninety years of nominal incorporation in the Ethiopian state, there are no government offices, no services, no transport facilities, no police or army posts in the Suri area (National Atlas of Ethiopia 1988: 35, and local information in Maji), and economic exploitation of the area is marginal. The advantage of this isolated position has been that the Suri were not bothered for taxes or other civil duties. ${ }^{2}$ They neither have (and never had) $k$ 'ebeles (local administrative units) or peasant associations, and are virtually autonomous in the maintenance of internal social order. Because of this image of remoteness, however, they have been sought out by foreign tourists seeking 'exotic tribes'. The appearance and peculiar behaviour of these tourists during the 1980s (paying Suri for photographs, trying to buy or swap their artefacts, etc.) has had negative effects on the Suri, who now are wary of all outsiders. ${ }^{3}$

The Suri consist of two subgroups: Tirma and Chai. ${ }^{4}$ Research was done among the latter. The Suri linguistically belong to the Southeast-Surmic language group (within the 'Nilo-Saharan' family), about which little information is available. ${ }^{5}$ They practice shifting cultivation of sorghum and maize (on a fairly primitive technological level), some gardening, transhumant pastoralism, and hunting and gathering.

\section{Environmental Conditions}

The Suri eco-niche - a limited natural environment with which they interact to find most of the products to sustain themselves - is a semi-arid lowland zone, between 500 and 1000 metres in altitude, ${ }^{6}$ covering about 4400 sq. km, which, obviously, is not fully inhabited everywhere. 
According to the National Atlas of Ethiopia (see note 6), rainfall is between 800 and $1200 \mathrm{~mm}$ per year. The average is certainly below $1000 \mathrm{~mm}$, and the pattern is rather unreliable, especially further south from the Dizi mountains. Rain is insufficient for permanent, intensive agriculture, and - as the drought-and-famine crises of the 1980s show - even for shifting cultivation of maize and sorghum. Most soils are fertile but rocky, and hardly suitable for plough agriculture. Vegetation cover consists of bushed shrubland, wooded grassland and remnants of riparian wood or shrubland along the Kibish River. The tse-tse fly is not widespread in the area, which means that, in principle, conditions for cattlekeeping are good. Game animals were, until about two decades ago, abundant but have diminished due to ferocious hunting by local people.? One perennial river, the Kibish, crosses the Suri area from north to south, flowing down from the Maji mountains to the area of the Nyangatom people (who have a different language and culture). Five to ten kilometres west is a smaller river, the Kiba. Between these two rivers, the best Suri grazing land is found. There is no flood-retreat cultivation along the river banks, as among the Mursi people east of the Omo. At the end of the dry season (March-April), there is a problem of water and pasture shortage, with staple food supplies often precarious.

\section{Ethnic Relations}

Neighbouring the Suri are the Nyangatom in the south, the Dizi and Me'en in the north-east, the Anuak in the far northwest, and east across the Omo river the Mursi (only the latter are closely related to them in language and culture).

Suri oral tradition maintains that they arrived in the lower Kibish and the Tirma range (a hill area north of Shulugui) at least fourteen generations ago, ${ }^{8}$ coming from the lower Omo River Valley, via the Dirga and Gherghetto hills. When they moved into their present habitat (including the now vacated part close to Shulugui), they did not find other people there; their Nyangatom neighbours (part of the 'Karimojong-cluster' and closely related to the Turkana) arrived later. With the Nyangatom (or 'Bume' as they call them), the Suri have always had a very tense relationship, although in times of relative peace the two groups had ritual bondfriendships and exchange partners. When moving to the north fringe of the Kibish valley, the Suri encountered the Dizi, long-settled agriculturalists in the highland zone. They established a ritual bond with them, under which the Dizi would perform a rain-ceremony for the Suri if they suf- fered from lack of rain in the valley. There is also a tradition that chiefly families of both groups are related and cannot intermarry. The groups were therefore traditionally on good terms.

With the Anuak, the Suri have no positive relations whatsoever, unless one considers the recent trade in automatic rifles (in the Dima area) as such. With the Mursi they intermarry and exchange cattle and other resources. They are seen as similar to the Suri. Also with the Me'en (also a Surmic-speaking group, with historical and cultural affinities) there was some intermarriage, but now the groups avoid each other because of conflicts. There is only significant contact between the agro-pastoral BodiMe'en (across the Omo River) and the eastern Suri who live below the Sai mountain, east of the town of Maji.

In the early years of this century, northern immigrants (Amhara, Oromo, Tigray, Gurage, and others) arrived, in the wake of the imperial army led by Emperor Menilik II's general Ras Wolde Giorgis, who founded Maji town and also temporarily subdued (or thought he did) the Suri in adjacent lowlands. The area was then one of adventurers and traders who, from their base in Maji, roamed the lowlands to buy, exchange or rob cattle from pastoral peoples like the Nyangatom, Dassanetch and Suri. Some northerners became influential local figures who carved out political spheres of influence extending well into the Toposa and Turkana country, then nominally British. Before settlement of colonial boundaries with the British (1905-1920), the northern Turkana area, for instance, was effectively the territory of the highland-Abyssinians led by gerazmach Aberra, from Tigray. ${ }^{9}$ Turkana oral tradition (see Lamphear 1992:155-6, 162) knows him as Apara.

In this century, the Suri oriented themselves to regional markets, especially Maji and Jeba, the two earliest highland villages founded in 1898, lying a three- to six-hour walk from their area. There they sold cattle and goats, and bought small trade items (cloth, salt, razor-blades, iron tools, grain). They also traded with Sudanese Bale and occasionally Murle people (livestock, beads), but their main orientation was toward Ethiopia (evident from their exclusive use of Ethiopian currency). Also, in Haile Selassie's time, the Suri were (for a few decades) administered by Ethiopian officials, who founded police posts and appointed district representatives in two small settlements in the area. While Ethiopian authorities were present, there was no effort to 'assimilate' the Suri. In terms of the hegemonic cultural ideology of the highlanders, the Suri were perhaps looked down upon - being seen as 'nomads', 'without religion', etc., and authorities' tried to discourage them from 'going around naked' and from inserting their large lip- and ear-plates. But the reverse was also true: the

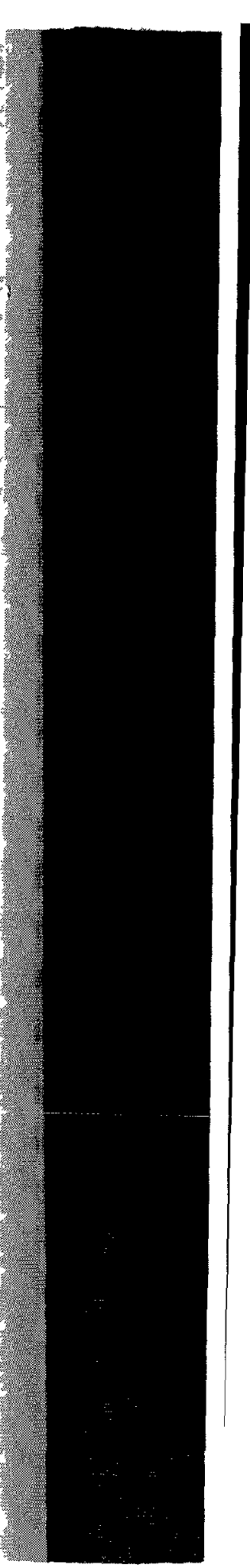


Suri had a disdain bordering on contempt for the highlanders. From their point of view, the latter were marginal to their society. Thus, mutual differences were recognized, with no party expecting them to disappear.

Despite contacts with various groups, the Suri have almost no proficiency in any other language than their own. If they have a second language it is, especially among the Tirma, Balethi, spoken by the closelyrelated Balé people. Some speak Nyangatom or Dizi; Dizi women who marry Suri men stop speaking Dizi and their children only learn TirmaChai. The Me'en, Anuak, or Murle languages are not spoken. Among the Chai, about thirty-five people speak Amharic, most of them former soldiers recruited by force or trickery for the National Army under Mengistu.

On the basis of environmental and ethnic relations it can be concluded that the Suri eco-niche is not a stable set of natural conditions, but is highly sensitive to differing patterns of rainfall, wild and domestic animal movement and human use of and competition for limited resources. It is difficult to sketch a clear picture of the resource base and number of people in the early decades of this century (just before the Northerners arrived, changing the political set-up with trade, slave-raiding, cattlerustling and a newly imposed administrative structure). But population distribution and settlement patterns at that time showed less density and less intensive resource use (e.g. of pasture, cultivation sites, trees and bush for firewood and building). ${ }^{10}$

Transhumant pastoralism, shifting cultivation of sorghum and maize, gardening and hunting and gathering still form the core of Suri subsistence. Fields for sorghum and maize (for which there still is sufficient unused bushland) are cleared and burned every year, although one plot may serve for two or three years. Technology is elementary: they only use machetes, hoes, and iron-pointed digging sticks. No other inputs (apart from collective labour, in exchange for sorghum beer) are known. As noted, the lower Kibish Valley provides excellent pasture for cattle. The Suri, recognizing herds as their security and future, invest any surplus in acquiring cattle. Cattle are not only used as food (blood, milk, occasionally meat) but also for clothing and utensils, constitute the main wealth transferred at marriage and have a role in many rituals. Also, the Suri keep goats and sheep. Leaves and fruits from various trees and shrubs are gathered especially by women and children. Women plant cabbage, pumpkin, gourds, peppers, and cassava - the only root-crop, but a major food resource. Hunting has always provided a good additional, though irregular, source of animal protein. In the early 1970 s, Suri hunting was seriously restricted by the creation of the Omo National Park. ${ }^{\text {II }}$

\section{THE FAMINE CRISIS}

Over the past two centuries, the Suri suffered badly from drought and famine. Their oral traditions indicate that cattle epidemics were not unknown but it appears that they were less devastated by the big rinderpest epidemic and famine of the 1890s than other southern peoples, like the Tishana-Me'en, Dizi, Mursi or Dassanetch. The most recent serious cattle plague was the anthrax epidemic in the early 1970s (probably imported from Sudan), which made large tracts of traditional grazing area around Mount Shulugui and along the Tirma Range unusable. Also in the 1970s, drought caused severe crop failure and cattle death especially among the Chai (the Suri section east of the Kibish River). David Turton mentioned this crisis in his studies on the Mursi (cf. Turton and Turton 1984: 187). In these years, the Suri subsistence base was slowly undermined; numbers of cattle and people declined, crop yields were small, and gathering roots and fruits could not yield sufficient nutrition to sustain the population. Also, the Suri were earlier prevented from hunting in Omo National Park, which was guarded by (at that time, better armed) game wardens. Thus, the Suri had neither food-reserves (grain or cattle) nor sufficient weapons, i.e. they could not retaliate for cattle raids from their neighbours (mainly Nyangatom).

In 1984 the rains failed again. The ensuing drought and famine period of 1984-85 forms the baseline for this analysis, although it must be emphasized that it had its precedents in a decade of crisis. In 1984-85, more Suri were dying because traditional responses of increased hunting and gathering, emergency selling of stock animals and raiding did not work and people were already weakened by preceding crisis years. Informants recall this period as the worst in recent history. In these years, the Suri lost several thousand people from all age-groups, and as the victims could not all be buried, corpses were left in the bush, covered with tree-branches and leaves. A possible contributory factor to the crisis, the increase of fatal contagious disease (intestinal infections, diarrhoea), cannot be assessed at the present state of knowledge, but was probably important '(see Kelly, this volume, Chapter 12)

Following traditional crisis-responses, several Suri groups migrated north to the Tulgit area, a Dizi border area west of Jeba town, to find new forest/bush resources, new grazing or cultivation lands, and to be near the town. Some 1000 to 1200 Tirma (Suri living west of the Kibish River) crossed into Sudan to exchange cattle for grain with local Bale and Anuak people and to find new cultivation sites on the southern fringe of the Boma Plateau. (A similar Tirma migration occurred early in this century.) For 
the same reasons, the Chai moved closer to the Maji foothills, considered a Dizi area For the Chai-Suri especially, an additional reason to move north was the persistent threat of the Nyangatom (see below).

Meanwhile news of the crisis reached local administrators in Maji, and eventually the Jimma and Addis Ababa offices of the Ethiopian Relief and Rehabilitation Commission (RRC) were notified. With World Vision International, an emergency famine relief programme was set up late in 1985. Planes landed at a small airstrip in the Kibish area (constructed by missionaries in the 1960s), and corn and grain were distributed. No camp was set up: the Suri collected their grain and returned to their homesteads nearby. Many lives were saved and, as in the similar Mursi case described by the Turtons (1984), no long-term dependency relationship was created between donors and recipients.

The Suri had no indigenous conception of outside 'aid' or 'development'. Aid by external groups was initially neither expected nor understood. There were traditional ways of appealing to bond-friends among neighbouring ethnic groups - a kind of 'structural reciprocity' - but, significantly, this did not work in the 1980s.

The Suri attitude toward outside agencies - which they only knew in the form of the Ethiopian government and a short-lived missionary effort in the 1960 s-early $1970 s^{12}$ - was sceptical and distant. They had had no contact with relief organizations when World Vision and the RRC stepped in. ${ }^{13}$ While they eagerly accepted grain given to them, they noted that it was a short term non-reciprocal event, and that they ultimately would have to rely on their own meagre resources and get whatever they could by their own effort. ${ }^{14}$

When the donors left after some months, natural and material conditions had not substantially improved. Crops were poor, cattle were scarce, game resources outside the Park area were being seriously depleted, and no new inputs in terms of sowing grain, draught animals, etc. were supplied. Recovery of their subsistence base was thus left to the Suri themselves.

\section{INTER-ETHNIC CONFLICT, 1984-93}

The other major contributory factor to crisis, coinciding with subsistence problems in Suri society was that of inter-ethnic movements, especially in the Ethio-Sudan-Kenyan border area. In roughly the same years that famine affected them, violent conflict emerged with the Nyangatom, their immediate neighbours. Several factors explain Nyangatom aggression towards the Suri: (a) pressure from Turkana people in Northern Kenya, who have steadily moved north, due to persistent drought, scarcity of grazing lands in their own habitat, and perhaps to political harrassment by Kenyan authorities. Several serious clashes with both parties were reported over the past decade, up to today; (b) high Nyangatom population growth and need for more grazing and cultivation sites, c) the southern Sudanese war. In 1982-4, the Toposa in Sudan acquired automatic rifles from either Sudanese government troops or illegal traders and traded them to the Nyangatom, their brethren and allies. Also, the Nyangatom bought them from traders and more recently may have gone as far as Malakal to get training and free weapons from government forces. ${ }^{15}$ This gave the Nyangatom a decisive edge over their traditional enemies the Suri (called by them 'Nyikoroma', hill-dwellers). They pursued them in their home territory, causing a disproportionate toll of human life among the Suri and loss of many cattle and small stock and of traditional grazing areas near Mt Shulugui.

One might even argue that this ecologically- and demographicallymotivated movement and its violent effects were the prime cause of starvation, because it undermined traditional Suri ability to respond to drought and crop-failure crises based on their own resources (i.e. cattle, huntinggathering, short-term migration). These developments forced them to concentrate in larger, more defensible villages, and (over-)exploit a more limited area. This resulted in relative crowding, depletion of bush resources for firewood, huts and cattle corrals, and in a fall in yields of cultivation sites (shorter fallow). The Nyangatom threat finally also induced the Suri to settle in their present locations along the upper Kibish, about 40 kilometres north of their core area.

Although most have now (1994) lived for six to seven years in the Dizi border area, many Suri see this as exile: their real 'homeland' is near Mt Shulugui, the place, as they say, where their main rituals (like the longawaited age-set initiation ceremony) should be held. But although they claim (ideologically, so to speak) that they want to return there, they realize that it may already be too late. The Nyangatom have settled at the base of the Shulugui mountain and now urge district authorities to recognize a new Nyangatom $k^{\prime}$ ebele on former Suri territory. They have also a strong EHADIG contingent there, partly made up of their own people. ${ }^{16}$

In the meantime, the Suri's northward push into fringes of Dizi (and perhaps Me'en) territory continues. Whether they will settle in the highlands and adopt cultivation, is another matter; so far no Suri (either individuals or family groups) have moved out of Suri country permanently (for one insignificant exception, see note 14). 


\section{ADAPTIVE RESPONSE AND REGENERATION, 1988-92}

In February 1988, during my first visit, the Suri were still suffering from effects of drought and famine. However, in late 1991, they had substantially recovered: many young children, large villages, large fields of sorghum and maize, herds restored to a remarkable degree compared with the 1985 situation. Migrant Suri even returned from Sudan to Ethiopia. Another indication of regained strength was that most adult males had an automatic rifle, the new symbol of power and male status. Next to the Nyangatom, the Suri thus became the best armed group in the area, and were (and still are) a serious threat to peace and security in the Maji area.

One secret of their recovery was increased exploitation of a unique resource: gold. Lower parts of the Maji-Kibish and the Upper Akobo areas, especially in and near streambeds, have small deposits of gold which can be extracted by panning. This practice was known among Diz and Anuak people. The latter mined gold near northern tributaries of the Akobo (Dima) river. Nobody knows exactly when this practice started, but it was probably during the Italian occupation (Italians sent prospecting teams to the area and set up a branch office of their mineral exploration company COMINA near the Akobo). The Suri say they became familiar with the practice about twenty years ago. But as mining is very hard work often done for several weeks, outside the Suri area proper in a kind of noman's land, they had never fully exploited this resource before. Neither did they use gold for any purpose within their own society. Only external demand - traders in Jeba and Maji - finally urged them to take up goldmining in the drought years. It yielded substantial cash with which they bought tools, food, and cattle, and, later, weapons. For 4.5 grams of pure gold (the work of a few weeks' mining, including travelling), they received about 300 Ethiopian birr (in 1986-7, U\$ 149), the price of one cow or bull, or two heifers. In 1991, the price was about 15 per cent higher, in mid-1993 again 5-10 per cent more. Thus, especially in 1986-90, there was something of a native goldrush to the Akobo area Gold was (illegally) sold not only to town-traders but also to Anuak people up north, who gave them cattle, bullets and Kalashnikovs in return (obtained from Sudanese army depots). Interestingly, the Suri never invested proceeds from gold in cultivation (i.e. in ploughs, draugh animals (oxen), tools, other crop seeds like t'eff or wheat, in permanent housing, etc.) but only in these two elements allowing them to reinforce their hold on their traditional eco-niche: cattle and guns. The Suri saw the need to arm themselves in order to re-assert claims to their own traditional area in the face of efforts by, especially, the Nyangatom, to monopolize resource niches (water sources, bush tracts and grazing land) in the southern border area near Shulugui. In other words, they wanted to 'restore the balance'. But the newly acquired weapons also tempted Suri to rard cattle from the Dizi, on whose lands they had steadily encroached since 1985. In 1991, there were at least four big raids on Dizi settlements, in which close to a hundred Dizi were killed. In 1992 and 1993 this continued, while Suri armed youngsters killed several old Dizi chiefs and also defenceless Dizi girls carrying water or firewood, or farmers returning from fields. Numerous cattle were stolen and property destroyed. Trade routes between Maji and Jeba were constantly threatened, and people moving to markets (village people, Tishana, Dizi) were ambushed, robbed and killed. In 1993 conflict escalated further so that large numbers of southern Dizi, tired of random killings, left their home areas to go north. Government action, either from the Derg or the EPRDF-led government, has been slow in coming but finally a crack-down of EHADIG-forces on the Suri at the end of 1993 seemed to have muted Suri aggression. ${ }^{17}$

In sum, gold and use of violence not only helped the Suri to survive their subsistence crisis, but also to obtain new power. By investing and using automatic rifles their recovery turned out to be too successful, so to speak.

Even though violence may be checked in the near future, at present it allows them to restore their way of life as they see fit. It is unlikely that the Suri - as sometimes expected by government or NGO representatives will make a transition to sedentary cultivation. The Turtons (1984) described such a settlement move by a part of the Mursi, who in a comparable period of crisis went to live as cultivators in the Mago highland area. But nowadays, this experimental settlement (where no cattle could be kept due to tsetse) has largely been abandoned: most Mursi returned to the plains. ${ }^{18}$ The Suri, like the Mursi, are reluctant to live as farmers in the highland zone, especially if there is an option to regain a foothold in the pastoralist economy. Like the Mursi, the Suri see themselves as a free herding people. Whatever cultural reasons there are for it, this attitude makes some economic sense: not only are the Suri relatively free from administration and tax-imposing government officials, they also can, in good years, accumulate much more wealth ${ }^{19}$ than, say, the Dizi or the Me'en, because of their substantial numbers of cattle. In addition, with their new weapons, the Suri also regained access to the last plentiful sources of game meat in Omo National Parks'. They were not disturbed by the Parks' game wardens, who feared Suri fire-power, although in 1993 an EHADIG-force was stationed there, which will discourage large-scale hunting. Of course, Suri weaponry also enabled them better access to gold, exploitation of which they have tried to monopolize, pushing out the Dizi. 


\section{SOCIAL AND POLITICAL EFFECTS OF CRISIS}

The main effects of drought, famine and political upheaval on Suri society can be noticed in three domains.

\section{Socio-economic Organization}

Initially, in the worst famine period, domestic units became more independent, with solidarity between agnates, clan members or fellow villagers eroding as resources declined. Also, a 'split' in domestic groups occurred: males and females operated more independently of each other. Related to this were changes in labour organization - between males and females and in labour-tasks themselves - most of which proved to be shortterm. Male household heads were more mobile, hunting, visiting the relief distribution point, selling cattle in various places, begging for food (e.g. among the Dizi), and going to gold-mining places. ${ }^{20}$ Clearing and planting declined, as seeds were used for consumption. Women and young children spent more time gathering. Women seemed less affected by famine. The number of female victims was lower than that of males. In recent years, as the Suri recovered, this led to increased polygamous marriages (also because of 'levirate' marriage: a man taking the wife (wives) of a deceased brother or other close agnatic relative).

Trade with highland villagers increased after 1985 . First, the Suri offered goats and cattle, in return for grain. Second, the role of gold as a commodity rapidly gained importance. In Maji and Jeba traders were happy to buy gold, which could be resold at a profit elsewhere. Increased market exchange, however, did not draw the Suri into the regional money economy. They used it to funnel resources into their own society, not to acquire other commodities except for salt, razor-blades or cloth. It was neither extensively used as measure of exchange, 'saving' or value within their own society: it was mainly seen as a medium for dealing with outsiders.

\section{Internal Political Relations}

A notable long-term effect was a change in the balance between generations within Suri society: elders (in Suri: bara, or in general, kumin) versus youngsters and younger married men (tègay) and junior elders (rora). Although the three komoru, or 'ritual leaders', retained their prestigeous (hereditary) position, their effective influence declined. Their advice on raiding, location of new fields or villages, control of ceremonial duelling contests, or on occasional government directives or proposals, was listened to but not seen as binding. Their mediatory functions were still called upon (during group conflict or public meetings) but their authority or 'executive power' (already poor in the traditional system) was reduced to virtually nothing in the years of crisis.

To illustrate, we look in some detail at a central Suri ritual, ceremonial male duelling (sagine). This is done with poles (dongen, sg. donga) of tough kallochi wood (Grewia mollis Juss.), 2.10 to 2.40 metres in length. Contestants are young men of the tègay age-grade (unmarried) from different territorial settlements and/or clans. They hold several matches and return-matches over a period of a few months every year. The short fights have to be supervised by referees (oddá). In functionalist terms one might maintain that these contests 'regulate' internal tensions generated between competing village communities in Suri society, in allowing young, ambitious men, eager to start life as independent household heads to show their strength and virility in a socially accepted manner (this aspect is explicitly recognized by nubile Suri girls). There is certainly more in it than this, but in fact the actual level of violence (harrassment, assault, theft, murder) within Suri society is low. However, the important point is that the sagine institution has undergone notable changes in the past six to seven years. First, frequency of contests has much increased. They are held almost every two to three weeks over a period of three to four months after the main sorghum harvest (September-November, and after that as well (e.g. in January and in the first rains in April-May). Second, influence of elders (including the komoru) and referees over contesting parties has diminished: nowadays, young men continue as they like, and after one party has 'lost' a contest, they grab their Kalashnikovs and start shooting (usually, but not always, in the air) to show their irritation. Suri elders say the game has lost much of its former attraction and its meaning is being eroded.

The increase in the number of contests is, from the perspective taken here, a predictable result of two underlying factors: a) mounting external pressure on Suri society from neighbouring groups, especially the Nyangatom, which has made them nervous and agressive but also unable (yet) to vent this agression against the Nyangatom without risking heavy losses, and: b) population pressure and decreased resources in a limited area. Resource use and population growth (at least 3.5 per cent per annum in the last four years ${ }^{21}$ ) have led to visible degradation of their immediate environment. Village communities live much closer to each other and must take each other's fields and bush resources into account, as they exploit the same places for gathering, firewood, washing, water, etc.. 
Relations become more competitive, leading to inter-community rivalry, expressed partly in donga contests.

The fact that young men have taken over the sagine-proceedings indicates their newly gained power-base (guns, cattle) within Suri society. Gold exploitation enables them to assert independence from fathers or other older agnates (who wish to use their labour as long as possible): they do not have to wait so long to start building up their own herd, or to marry.

A related effect is the increased self-confidence of the Suri after having recovered from crisis. This is what village people and the Dizi mean when they say the Suri have become 'arrogant', 'saturated' (Amharic: t'egabeñña). One sees this in the expression of violence with automatic weapons, which has had a kind of cultural effect in itself, tending to stimulate a 'cult' of the gun among Suri youngsters.

\section{Inter-group Relations}

Although gold-mining enabled the Suri to gain cash and expand cattle herds, this has not led to repossession of former areas of settlement close to the Nyangatom area - which would have eased the abovementioned demographic and ecological pressures. The system of inter-ethnic relations is as strained as ever. One might associate this development with the TGE's new ethnic policies but, as is clear from the preceding analysis, deterioriation started well before the change of government. The Suri are also still one of the least politicized groups in Ethiopia, having avoided the heavy ideological pressure on ethnic identity development, etc., through their isolated position and limited exposure to highland culture. Remarkably, although they know from experience what the highland socio-cultural model of life implies, they are not in the least drawn to it. There is a persistent, largely sceptical and negative, image of highland Ethiopians (in Suri: Golach, which includes Amhara, Tigray, Gurage, Oromo) as opposed to their own self-image as proud, independent cattle-herders with distinctive customs like female lip-plates, body decoration, ceremonial duelling, and specific initiation rituals. Change of government has not significantly modified this attitude. The EHADIG is seen as another representative of highland society.

While the TGE's policy is to stimulate ethnic group self-organization and representation on local and regional levels, in the case of the Suri this cannot be easily applied. While the Me'en formed a self-organization (not a 'party') under EHADIG auspices, the Suri have no interest in this. Neither it is likely that they will join the Käfa Peoples' Democratic Movement, which has a Dizi academic as one of its leaders. In the Maji area, there are serious debates about boundaries, compensation for past raids and killings, resource exploitation and secure trade routes. As long as outstanding disputes (on recent Suri expansion into Dizi lands, their killing of Dizi leaders and ambushing trading parties in an area jointly used by all groups) are not solved, it is difficult to see how regional-ethnic autonomy could work. In such conditions, government troops are needed as intermediaries maintaining a semblance of law and order.

Thus, the Suri - and the other groups - do not share in the newly propagated political discourse on ethnic group identity. They follow preexisting, socio-ecologically rooted, group images, which are partly complementary and partly antagonistic, and which emanate largely from regional-level political group relations and from daily economic concerns.

Traditional mediatory channels through elders and established ritual mechanisms seem to have lost their importance and consensus between ethnic groups has given way to confrontation. As this also seriously impairs trade and exchange relations, each group unwittingly develops the need to rely on its own resources, and to aim at a false self-sufficiency (cf. Abbink 1994). This response is not simply due to deterioration of the natural environment in itself - because in earlier times, conflicts and crises were more or less contained and concluded in temporary, ritually sealed, reconciliation. Such a response is decisively aggravated by the uncontrolled spread of modern arms, creating an unpredictable, insecure political environment. As such regional problems of proliferation of arms cannot be solved easily except by massive disarming - this instability will remain and continue to reinforce traditional tensions and overexploitation of precarious resource bases for increasing numbers of people. Paradoxically, for the new political models of ethnic autonomy and representation to work, a new framework of inter-ethnic mediation would be required, to be organized along the lines of traditional arrangements, de-emphasizing the usurped power of youngsters with guns. Development schemes would have to stimulate joint involvement of various ethnic groups (because there is no numerically and territorially dominant group in the Maji area).

One development project is currently underway among the Suri - it could be seen as another effect of the serious crisis of 1984-5. This is the 'Surma rehabilitation project', set up by the Lutheran World Federation and the Ethiopian Evangelical Church Mekane Yesus. From 1989 to 1993 they were in a base camp in Tum, the small district capital of Maji zone. Late in 1993, another base was being built in Tulgit, at the north fringe of the Suri area. While the project has missionary aspects (e.g., translating the Bible and other Christian texts into Suri) the aims are to open a clinic, improve cultivation techniques, give veterinary services, and eventually a open a primary school. While medical services have up to now been provided to 
the Dizi and the Tum townspeople, the Tulgit project will be geared chiefly to the Suri. It will certainly attract a number of Suri youngsters but whether it will lead to basic changes in the Suri way of life is doubtful.

\section{CONCLUSION}

The Suri have been able to get out of their crisis by timely exploitation of gold as a cash resource, which was 'invested' back into their transhumant pastoral economy, in the form of cattle and weapons. The were able to regenerate their reproductive powers in a double sense: more cattle (either bought or raided) allowed a quick upsurge in marriages and births; and acquisition and use of weapons which permitted self-defence and expansion at the cost of others. Availability of automatic rifles also led to changes within Suri society itself: generational tension, territorial disputes, and rivalry between Tirma and Chai sub-groups. An unintended effect of Suri self-rehabilitation is that the role and use of arms has acquired a cultural momentum of its own, with far-reaching effects on Suri social structure and on ethnic group relations (cf. Abbink 1994).

The perhaps atypical recovery of the Suri - which temporarily decreased their inter-dependence with other groups in the ethno-system - does not solve problems of long-term vulnerability of their environment and way of life (this is not something foremost in the Suri mind; they seldom speak of the famine of the past and think the weapons give them an enduring power base). The main problems of the Suri eco-niche remain:

1. Unreliable rainfall, affecting pasture and bush resources;

2. Unstable relations between expanding, competing ethnic populations in a partially shared area with limited resources;

3. Unpredictable (national) government policies;

4. Exîernal threats due to regional conficts spilling over into adjacent areas (Northern Kenya, Southern Sudan). When state influence (administrative, military or police presence) is relaxed, local conflicts will be played out increasingly by force. A political-administrative emphasis on ethnic group identities and boundaries will, most likely, not ease group tensions in Maji area, where groups have traditionally been partly dependent upon each other.

While this chapter indicates that disaster-affected people can develop their own adaptive response to subsistence crises, and that external aid should be geared to that, it is far less certain what must be done if this response is formulated, so to speak, at the expense of others.
Obviously, indigenous views should be considered, including the 'target' group's possible inclination to reject aid if it has perceived drawbacks. Sustainable development programmes, insofar as they have any long-term chance in a still unfavourable macro-economic setting, should be grafted upon serious consideration of local conditions and, in this case, implies recognizing Suri wishes to maintain their agro-pastoralist economy; taking into account short-term migratory patterns; recognizing environmental limits and possibilities for agricultural crops and techniques; respecting the central role of women in family life and in most subsistence activities; and acknowledging gathering plants, roots, nuts and fruits as important components in their food portfolio. If 'cultivation projects' are envisaged, examples should be provided in irrigation agriculture along the Kibish, but with crops the Suri prefer. Obviously, improvement is required in transport, educational and medical facilities, giving the Suri a choice to eventually participate in the regional or national economy. This applies to the (multi-ethnic) region as a whole.

There must be a response to eventual Suri desires to enter into more close relations with other groups or government agencies, but they should not be forced into a marginal economy which destroys the remarkable measure of self-reliance and cultural stability they now possess.

\section{Acknowledgements}

I thank Dr David Turton, editor of Disasters - Journal of Disaster Studies and Management, for permission to use material first published in that journal in 1993 (Disasters, 17(3): 218-25). Generous support by the Royal Netherlands Academy of Science (KNAW) and the Netherlands Organisation for Scientific Research in the Tropics (WOTRO) for my fieldwork in Ethiopia (1991-3) is gratefully acknowledged. I am also very grateful to Suri friends for help and hospitality, among them Barhoyne Wolesirba, Wolekibo Wara, and especially Londosa Doleti. Finally, I thank the Institute of Ethiopian Studies at Addis Ababa University for its interest and assistance.

\section{Notes}

This figure is based on census work in 1991-2. Existing statistics on the Suri/Surma are scarce and unreliable. The local administration in Maj1 keeps no population records for them. In 1985, World Vision International made a preliminary census and came to an estimated, but inflated, figure of about 35,000 . This was during the famine. 
2. I exclude here the Bale or Balethi people who might be considered a third Suri group (see Lyth 1947). They are closely related, especially to the Tirma and number about 8000 . However, most live in Sudan east of the Boma plateau.

3. The Suri have repeatedly stolen unattended things from tourists. They see the tourists' behaviour as unresponsive, exploitative and non-reciprocal and basically do not understand what they want. In the meantime, the security situation in the area (late 1993 - early 1994) has deteriorated so much that to visit the Suri as a tourist would be near-suicidal (see Abbink 1993). Organized the Suri as a tourist would several years ago and a new effort in October 1993 failed. For a kind of 'tourist view' of the Suri, see Beckwith and Fisher $(1990 ; 1991)$, interesting but in several ways inappropriate accounts.

4. See T. Girard, report of abortive Suri survey, SLLE Reports (Addis Ababa) no. 4 (1993):10-24, and G. Dimmendaal on the Suri/Mursi and related groups, ibid., 26-7. Cf. J. Abbink, 'Suri-English Basic Vocabulary', Frankfurter Afrikanische Blätter, forthcoming.

5. For these data see the National Atlas of Ethiopia, pp. 7-8, 10-12, 18

6. Also, Western tourists with a permit obtained from Addis Ababa's Ethiopian National Tourist Organization (for thousands of US dollars) hunted in the area, much resented by local people.

7. This was the longest genealogy I could find (among the Chai Suri).

8. Information from Abba Fanta Yimer, a senior resident of Maji (July 1993). He was a soldier in the area shortly after Aberra's exploits in the early decades of this century.

9. Cf. Viezzer (1938) and Rizetto (1941) for the earliest reports on the Suri area.

10. See Turton (1987) for a study of the effects of the Omo National Park on the Mursi.

11. A mission with a small airstrip and a clinic was built in Merdur in the Tirma area. It was abandoned in the 1970 s when the Ethiopian government accused all American missionaries of being CIA agents. The buildings and materials were later destroyed and used by local people.

12. Even in this emergency period, several unfortunate incidents troubled relationships between Suri and outside agencies. One instance was the following: in Jeba village a government shack contained bags of powdery poison for treating crops. The Suri learned of this and believed it to be flour that was being withheld from them. One night they stole the bags and when they later used the contents to prepare flour porridge, several people died. They then blamed the village people and the administration for trying to poison them.

13. There had been some half-hearted rehabilitation attempts by the RRC and World Vision International, meant to introduce farming in the Kibish area but these were unsuccessful. Another attempt was made in 1985 when about five hundred Suri were taken outside the area to be 'trained in farming' (see Abbink 1992). This was also a failure, as 85 per cent of the migrants returned to their area of origin; the high rate of return migration also indicates that the Suri were successful in gradually restoring their traditional subsistence base in their home area, on which they knew they would depend in the future.
14. Some of this information was confirmed to me by Professor Serge Tornay (Université de Paris, Nanterre), foremost expert on the Nyangatom, in private conversation in Addis Ababa (January 1992) and in subsequent letters.

15. The EHADIG force in Maji have no Suri members.

16. In November 1993, a large-scale battle between Suri and EHADIG forces erupted, after Suri killed some EHADIG soldiers. EHADIG patience and restraint had already been severely tried when the Suri shot and killed one of their men in April 1993 and later defiantly exhumed and burnt the corpse. The night-long battle left many Suri dead and may have been a turning point in relations of the Suri with other groups in the area.

17. As mentioned in two recent films about the Mursi, The Land is Bad and Nitha (D. Turton and L. Woodhead, Granada Television, 1991).

18. This wealth is, however, not converted or reckoned in money but in terms of reproductive powers (family) and social standing (alliances) within their own society.

19. Suri (after the Kibish food distribution point was closed) continued to visit Dima refugee camp (for Sudanese refugees) to obtain food. It was located on the Akobo river, a two-day walk north, and was a major training and support base for the Sudan People's Liberation Army (SPLA), supported by the Mengistu regime. Retreating SPLA troops pillaged the camp in June 1991

20. Based on field census data 1991.

\section{References}

Abbink, J., 1990. 'Tribal formation on the Ethiopian fringe: toward a history of the 'Tishana'.' Northeast African Studies, 12(1): 21-42.

Abbink, J., 1991. 'The Deconstruction of 'Tribe': Ethnicity and Politics in Southwestern Ethiopia', Journal of Ethiopian Studies, 24:1-21.

Abbink, J., 1992. 'Settling the Surma: Notes on an Ethiopian Relief Experiment,' Human Organization, 50(2): 174-80.

Abbink, J., 1993. 'Ethnic Conflict in the 'Tribal' Zone: the Dizi and Suri in Southern Ethiopia', Journal of Modern African Studies, 31(4): 675-82.

Abbink, J., 1994. 'Changing Patterns of Ethnic Violence: Peasant-Pastoralist Confrontation in Southern Ethiopia', Sociologus (in press).

Beckwith, C. and Fisher, A., 1990. African Ark. Peoples of the Horn (London: Collins Harvill).

Beckwith, C. and Fisher, A., 'The Eloquent Surma of Ethiopia', National Geographic, 179(2): 77-99.

Chagnon, N., 1992. Yanomamö. The Last Days of Eden (New York: Harcourt, Brace, Jovanovich).

De Waal, A., 1989. Famine that Kills: Darfur, Sudan, 1984-1985 (Oxford: Clarendon Press).

Ethiopian Mapping Agency, 1988. National Atlas of Ethiopia (Addis Ababa: EMA).

Lamphear, J., 1992. The Scattering Time. Turkana Responses to Colonial Rule, (Oxford: Clarendon Press). 
Lyth, R., 1947. 'The Suri Tribe', Sudan Notes and Records, 28:106-114.

Office of the Population and Housing Census Commission, 1988. Analytical Report on Keffa Region. Population and Housing Census 1984 (Addis Ababa: Central Statistical Authority).

Rizetto, F., 1941. 'Alcune notizie sui Tirma', Annali d'Africa Orientale Italiana, 4:1201-11.

Turton, D., 1987. 'The Mursi and National Park Development in the Lower Omo Valley', D. Anderson and R. Grove (eds). Conservation in Africa: People, Politics, and Practices (Cambridge: Cambridge University Press).

Turton, D. and P. Turton, 1984. 'Spontaneous Resettlement after Drought: an Ethiopian Example', Disasters, 8:178-89.

Viezzer, C., 1938. 'Diario di una carovana di missione geomineraria di BongaMagi-Tirma dell'Ovest etiopico', Rassegna Mineraria Mensile, 17:404-425.

Walle Engedayehu, 1993. 'Ethiopia: Democracy and the Politics of Ethnicity', Africa Today, 40(2):29-52. 